\title{
MEMÓRIA DE DIAS QUE VIRÃO
}

\author{
Rodrigo do Prado Bittencourt 1
}

Seu João Sapateiro, como o nome já diz, era sapateiro de profissão. Também de tradição, já que seu pai foi sapateiro também. Seu pai, o homem a quem Seu João obedeceu até a morte, sem nunca pestanejar. Culpa?

Ele morava em Caxeamçu, pequeno vilarejo que existiu perdido no meio da floresta amazônica. Existiu, porque dele só restou mesmo o Seu João - resto de Isarel. Com o surto de malária, os outros fugiram ou morreram.

O Sapateiro não foi. Não por falta de oportunidade: muitos o convidaram a migrar com eles. Não quis. Diziam que era bobeira amar tanto a terra daquele jeito, que a vida era mais importante. Ele ficou calado, deu de ombros. O que só disse, no finalzinho, foi: "Da minha vida, da minha morte... Deus deu, Ele tira. Ninguém não bule."

Quando o padre, que ia ao local apenas uma vez por mês celebrar a Missa, foi retirar da capela o Santíssimo, pois o local ficaria abandonado, procurou Seu João e disse que o levaria dali. Seu João, devoto e obediente, disse:

- "Com todo respeito, Seu Padre, não saio daqui, não. Não carece. Passarinho que voa, esquece como andar".

O padre insistiu, disse que estava levando embora o Sacramento: nem DEUS ficaria ali. Pois o Sapateiro ficou.

\footnotetext{
${ }^{1}$ Mestrando em Teoria e História Literária pela UNICAMP.
} 
Auto exilado em terra sua, ele continuou a vida, como sempre: levantava cedo, ia cuidar das coisas que plantava; caçar, e de tarde, quando o Sol estava muito quente, se sentava na sombra para consertar sapatos. "Oficio que o senhor meu pai me ensinou".

Consertou tudo que tinha para consertar, botou todo o serviço atrasado em dia e, depois de não haver mais sapatos que precisassem de seus préstimos, começou a procurar um jeito de criar sandálias com cascas de árvores e palhas, para não deixar o oficio.

Seu João nunca casara; era pobre, despossuído de beleza e bens. Por isso sempre cuidou muito de sua aparência, desejoso de um dia ainda arrumar alguém. Aparava bem a barba, cortava sempre as unhas e zelava por sua roupa, costurando remendos e pregando botões. Limpava bem sua casinha de madeira, como se fosse receber visita, deixando tudo arrumadinho.

O mais curioso é que uma vez por mês, punha sua roupa branca e ia à Missa, mesmo sabendo que não teria ter padre, Missa, nem nada. Ele entrava na capela, se ajoelhava, fazia o em-nome-do -Pai e ficava lembrando de tudo que se faz numa Missa: ajoelhando, sentando, ficando em pé, dando as respostas e até para a fila de comunhão ele ia, com muita fé. "Herança de pobre é fé e vontade de trabalhar, senhor meu pai dizia."

Quando, depois de muito tempo, homens chegaram para cortar as madeiras da região, foi que encontraram Seu João nessa mesma vidinha de sempre, em paz e cordato. Primeiro o tomaram por maluco. Quem viveria assim? Depois, povo ambicioso, pensaram que ele não saía dali porque tinha algum tesouro escondido. "Quem sabe Seu João não fora garimpeiro em Serra Pelada e se enriquecera, enterrando tudo para no futuro comprar terras, virar fazendeirão, possuidor?!”

Os homens foram então conversar com ele, descobrir o que é que ele tinha, por que não saía dali de jeito nenhum. Dizer ele não dizia. Mudo, continuava a fazer o que já vinha fazendo. No final, apenas perguntava: “o senhor tem algum sapato precisando de conserto?" Assim, o enigma continuou e novas hipóteses surgiram: seria Seu João 
filho de índios e por isso acostumado ao mato e desacostumado das pessoas? Seria dono de doença horrivel e queria ficar sozinho - fora ele que passara a doença para os outros moradores antigos? Incertezas.

Seu João não se agastava com a companhia dos cortadores de madeira, mas não a procurava também. Tudo igual e nos conformes, para ele. Até que sua fama chegou ao fazendeiro, dono de tudo ali, patrão de homens. Ele foi pessoalmente conhecer o Solitário. Sabendo dos costumes do isolado, trouxe umas botinas e sapatos velhos para conserto. Seu João ficou alegre.

Vendo os quadros de santos na casinha, o fazendeiro foi falando de religião, de que o povo não acredita mais em nada, que ninguém mais tem fé e respeito... Sorriso na boca de Seu João. Com a confiança conquistada, ele perguntou por que Seu João não saíra dali e por que continuava a viver a mesma vida de sempre. Era por causa da terra? De parentes enterrados? Medo de morrer em outro lugar? Promessa?... Não, não era nada disso.

- "Era o quê então?", disse o fazendeiro, esperando descobrir um grande segredo.

- "Nada", respondeu o sapateiro.

Enquanto muitos iriam embora, desacorçoados, o fazendeiro insistiu: não pensou que seu candidato a santo ou sábio era apenas um parvo. Então, olhou no fundo dos olhos de Seu João. Eles não transpareciam loucura, inocência, ou iluminação divina... Nada! Nada além de um homem comum. Não um parvo, mas um homem. Só.

Aturdido pela normalidade, o fazendeiro voltou à carga:

-"Por que ficou aqui, Seu João?"

- "Por que não?", disse o solitário.

O fazendeiro calou. Pensou, instigado, e resolveu: ficou com Seu João. Nem precisou falar nada. Apenas tirou as botas, afrouxou o cinto e o outro entendeu. Não fez nada demais para recebê-lo, porém, apenas levantou e foi pescar. Para o fazendeiro aquilo significava "libertação." A vida, afinal, é mais que trabalho e posses. Vivendo em função do 
dinheiro, não se aprecia o Sol, não se degusta o arroz com feijão, não se percebe a delícia de tomar chuva no tempo do calor...

Como o fazendeiro demorasse, a família mandou um dos empregados buscá-lo. Ele disse que não iria. O homem voltou sozinho. A mulher do fazendeiro resolveu ir pessoalmente, buscar o seu marido.

Ele disse que não iria. Ela perguntou por quê? Ele disse "Por que sim?" e a convidou para ficar lá, com ele também. Irritada, voltou para casa. Escreveu carta para os filhos, que moravam na cidade. Eles vieram. Trouxeram o pai de volta à força e ainda mandaram dar uma surra no Seu João Sapateiro.

Em casa, falavam dos negócios, propriedades, para ver se agradavam o homem e o tiravam daquela demência. Nada! Quanto mais falavam, mais triste ele ficava e foi ficando cada vez mais calado; comia pouco. Chamaram o médico. Não adiantou.

Até que a sua esposa morreu. Ele não chorou. Ao contrário, sorria enquanto passava a mão na testa dela, no caixão, todo em paz e puro. Os filhos tiveram vergonha, mas não podiam tirá-lo do velório. Há muito escondiam o pai para que ninguém visse suas estranhezas, mas agora não podiam.

Pensaram, então, “o que fazer?" Levá-lo para a cidade? Daria trabalho? Interná-lo num hospício? Judiariam dele à toa e era vergonhoso. Conversaram com ele, perguntaram o que ele queria. Ele disse que não queria nada. "Tudo está bem."

Disseram que não poderia ser, que ele tinha de querer algo. Todos querem alguma coisa. Ele disse: "Por quê?" Os filhos não sabiam responder. O mais novo se irritou e saiu de perto. O mais velho sorriu, sem graça.

O fazendeiro ficou morando na sua casa, com toda a simplicidade. Os filhos vinham de tempos em tempos, supervisionar as contas da fazenda e viam o pai sujo de esterco, plantando milho ou limpando o chiqueiro. Não entendiam o porquê.

Crianças nasceram. Trouxeram para ele conhecer. Ele dizia, alegre: "Meus netos" e ficava olhando para elas, como se fossem de 
outro mundo, seres estranhos. Ou não. Ou muito próximos, muito parecidos. Verdadeiros.

Enquanto isso, Seu João continuava na sua vidinha de sempre, lá na casa em que nascera. Os dois não se viram mais. Os filhos do fazendeiro o proibiram de ir ver o Sapateiro. Ainda mais agora, que o pai estava viúvo e não tinha mais quem o vigiasse. Ainda assim, ele aprontava das suas. Não cuidava de suas posses e se tinha dinheiro e lhe pediam, dava sem pestanejar. Também não fazia caso do trabalho de seus empregados, tendo o capataz que cuidava de tudo, pois senão ele dispensava todos mais cedo.

Assim, ele viveu. As pessoas do lugar diziam que ele era santo e ele não dizia nada. Quando ficou doente e estava para morrer, trouxeram Seu João Sapateiro, já velhinho, para vê-lo. Seu João sentou numa cadeira do lado da cama e ficou. Não falou nada. Nem olhava para o doente. Os filhos repreenderam-lhe, ríspidos, disseram que deveria falar com o fazendeiro, que para isso o haviam trazido até ali. $\mathrm{Na}$ verdade, nunca o perdoaram. Ele só disse: “Sou assim quieto, como era o senhor meu pai." Mudo continuou.

Ficaram horas, assim. Quando alguém foi dar os remédios, viu que tinham morrido os dois. No velório deles, os filhos do fazendeiro não choravam. Nem mesmo entendiam porque não conseguiam sentir tristeza... Assim passou. Ninguém não tendo coragem de dizer nada das andanças da vida. Fato e silêncio: é.

Os filhos do fazendeiro, agora já velhinhos, nem comentam mais sobre seu pai. Eles se afastaram dele depois que ele conheceu o Sapateiro. Achavam-no insipido e idealista. O mais novo chegava a chamá-lo de louco, quando se irava com alguma recordação que não o agradava.

$\mathrm{Eu}$, que sou neto desse fazendeiro, é que resolvi correr atrás de sua história, desvendar seu mistério. O que descobri, falando com pessoas da região, que o conheceram e conheceram o tal João Sapateiro, foi o que me assustou. Contou-me um vizinho do meu avô algumas coisas que eu já sabia e nada mais. Ninguém mais se lembrava 
deles. Tudo passou e acabou. Nada restou dos homens que viveram uma vida tão incomum. Nem mesmo os que já eram vivos na época puderam se recordar de algo.

Decepcionei-me, pois pensei que meu avô fosse uma lenda na região. Ainda mais diante dos relatos de meu pai sobre as preocupações dele a respeito do que os outros poderiam pensar de meu avô, mas nada sobrou. Fato é. Tanta luta... Para quê? 